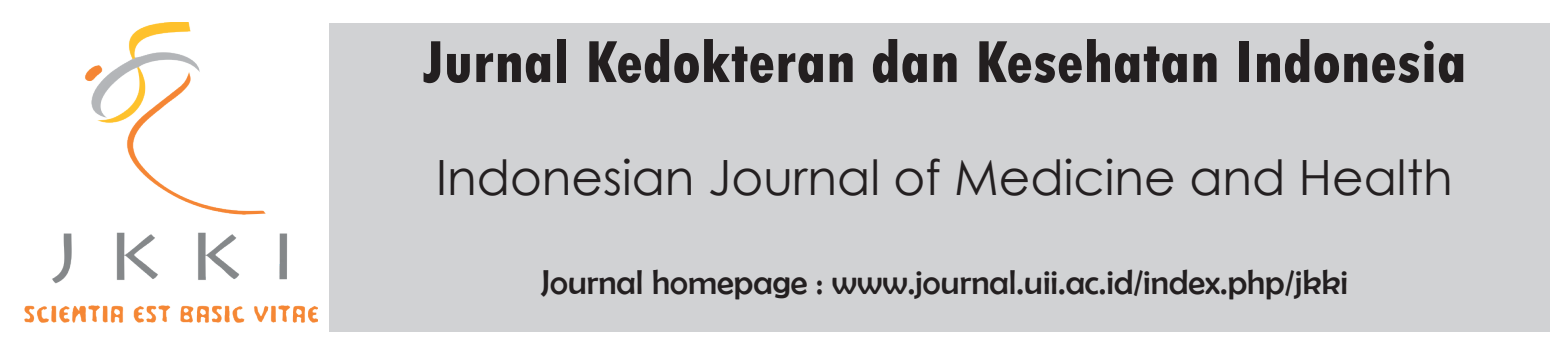

\title{
Inflammation and wound diabetic
}

Kintoko $^{1}$

${ }^{1}$ Faculty of Pharmacy, Ahmad Dahlan University Yogyakarta

\begin{tabular}{|c|c|}
\hline & EDITORIAL \\
\hline ARTICLE INFO & \\
\hline $\begin{array}{l}\text { *Corresponding author: } \\
\text { maskinjogja@yahoo.com.sg }\end{array}$ & $\begin{array}{l}\text { remodelling. The coagulation phase is the first stage of the wound } \\
\text { healing proccess which involves platelet cells. }{ }^{1} \text { The inflammation phase }\end{array}$ \\
\hline DOI : 10.20885/JKKI.Vol7.Iss3.art1 & $\begin{array}{l}\text { starts a few minutes after injury and then continues for several days. } \\
\text { During this phase, antiinflammatory cells adhere into the site of injury } \\
\text { and actively perform a mobilization with leukocytes (polimorfonucler- } \\
\text { leukocytes or neutrophil). If there is no interaction and contamination } \\
\text { in the inflammatory phase, it will develope to the proliferative phase } \\
\text { of healing. The proliferative phase is characterized by the formation } \\
\text { of granulation tissue in the wound and contraction. This phase will } \\
\text { be the end if dermis epithelial and collagen layer resurface the wound, } \\
\text { the wound begins to contract and a number of growth factors which } \\
\text { is produced by macrofag and platelet will accelerate this contraction. } \\
\text { The remodelling phase starts approximately the third week after } \\
\text { wounding and usually lasts about } 12 \text { months. The collagen synthesis } \\
\text { which started in the beginning of the proliferative phase will continue } \\
\text { in the maturation phase. The gelatinous collagen which is secreted in } \\
\text { the proliferative phase will realign to mature collagen tissue which } \\
\text { are stronger and better than gelatinous collagen. }{ }^{1}\end{array}$ \\
\hline
\end{tabular}

The complete healing of the wound will be happen if there is a continuity of skin layer and skin tissue strenghthen or it does not interfere normal activity. Although each person has the same wound healing proccess, the result of wound healing depends on their biological condition, site of injury and extent of injury. At the tender age and good condition (no comorbid), the wound healing proccess will be faster to complete than a person with malnutrition, comorbid (systemic disease) such as diabetes mellitus. ${ }^{1}$

Diabetic ulcer is a condition that occurs when skin tissue has broken down starting from the epidermis, dermis, subcutaneus and spreading to the deep tissue like bone and muscle. ${ }^{2}$ The stage of diabetic wound divided into three stages: superficial, deep and ulcus gangrene. ${ }^{3}$ The characteristic of diabetes skin, in terms of the dermis layer, usually appear thicker than normal skin. Hyperglicemia contribute to this condition by interfering collagen degradation so that the skin appears less elastic. ${ }^{4}$

Diabetic wound, chronic or poor healing, is the most complicated in diabetes mellitus. The chronic diabetic wound is caused by impairment of the wound healing proccess. ${ }^{5}$ In a diabetes mellitus patient, there is an increase of pro-inflammation cytokine during the wound healing proccess 
resulting in the inflammation phase and no progress in healing. ${ }^{6}$ Inflammation is very important in the healing proccess, however if there is an exaggerated inflammatory response, it will cause a longer wound healing proccess. Moreover, neuropathy factor, microangiopathy, and impaired imune system contribute to a delayed diabetic wound healing. ${ }^{7}$ The delayed inflammatory phase causes not only an increase of matrix metalloproteinase ${ }^{9}$ in the wound area but also a decrease of an inhibitor number. Both conditions can increase matrix degradation proccess in the wound area and tissue damage which contribute to delayed diabetic wound healing. ${ }^{8}$

\section{REFERENCES:}

1. Smeltzer S C, Buku Ajar Keperawatan Medikal Bedah Brunner Suddarth, EGC, Jakarta. 2002.

2. Junaidi I, Kencing Manis. Kelompok Gramedia, Jakarta. 2009.

3. Firman G. Wagner and the University of Texas Wound Classification Systems of Diabetic Foot Ulcers, 1-2, Medical Criteria, Texas. 2009.

4. Moffat C, Martin R, Smithdale R. Essential Clinical Skills for Nurses:Leg Ulcer Management, Blackwell Publishing, Victoria. 2007.

5. Schlutz GS, Mast BA. Molecular analysis and the environments of healing and chronic wounds: cytokines, proteases and growth factors, Journal Florida, 10:1F-9F. 1999.

6. Pearce C E. Anatomi dan Fisiologi untuk Paramedis, PT. Gramedia Pustaka Utama, Jakarta. 2009.

7. DiPietro LA, Guo S. Factor Affecting Wound Healing, US National Library of Medicine National Institute of Health Journal, 2009;89(3):219-29.

8. Harding KG, Jeffcoate WJ, Price P. Wound Healing and Treatments for People with Diabetic Foot Ulcers, Diabet Metab Res Rev Journal,2004; 20(1): S78-S89. 